\title{
MIGRATIONS OF DIURNAL BIRDS OF PREY IN THE ROCKY MOUNTAIN FOOTHILLS WEST OF COCHRANE, ALBERTA
}

\author{
by Dick Dekker, 3819 - 112A Street, Edmonton
}

In the absence of marked topographic features which would tend to channel migrant raptors, these birds pass over Alberta along a wide front. Not even the Rocky Mountains, which in this region rise gently from the plains in a series of irregularlyformed foothills, have much influence in concentrating raptor movements. Nevertheless, there is an impressive migration in the foothills region.

My observations were made west of Cochrane, Alberta, on 83 days over a period of eight years, in both spring and fall and on several occasions during the summer and winter (Table 1). Cochrane lies about 30 miles east of the Rocky Mountains. The observation area is west of Cochrane on private ranch land where trespassing is unwelcome, hence the exact location of the study area is omitted. The lowest elevation of the area is about 3,500 feet. The area is traversed by the Bow River, which flows in an easterly direction. Its valley is about one mile wide. Along this valley, south-facing slopes are semi-arid and grasscovered as far west as Morley, while the hills to the south are largely forested. On the grassy slopes, Richardson's ground squirrels (Citellus richardsonii) form an abundant food supply for the following raptors that breed or spend the summer in the area: Goshawk (Accipiter gentilis), Cooper's Hawk (Accipiter cooperii), Red-tailed Hawk (Buteo jamaicensus), Swainson's Hawk (Buteo jamaicensus), Swainson's Hawk (Buteo swansonii), Golden Eagle (Aquila chrusaetos), and Prairie Falcon (Falco mexicanus).

I have seen Goshawk, Golden Eagle and Prairie Falcon in every month of the year. All six of the above species are encountered from the last week of March until the middle of October. For this reason the counting of rap- tors in spring and fall does not give a true picture of the number of migrants. Another complicating factor is that many migrating raptors, especially the eagles, appear to stay in the area for some time, attracted by the abundance of ground squirrels. Therefore, I have rarely attempted to count individual birds, unless it was obvious that the raptors in question were migrating, as was the case with the fall flight of Sharp-shinned Hawks (Accipiter striatus) and sometimes with the eagles.

\section{Techniques of Observation}

As a rule my observations were made from the top of a high hill which allowed unobstructed view for many miles. The birds that I saw were travelling along a broad front. Observations were usually begun around 10:00 a.m. Even at that late time hardly any hawks or eagles were stirring in the hills, especially when it was calm, or when the wind was blowing from the east or the north. The prevailing wind is the Chinook, a strong westerly wind, which frequently gusts up to 50 miles an hour. When the Chinook blows, there are only a few clouds in the sky. This combination of strong winds and sunshine is typical of a good hawkwatching day. Usually, observation days lasted until late afternoon. When exceptionally strong and chilling winds forced me to lower levels, only part of the day was actually spent on the hill-top. Ofiten I have forsaken counting of hawks to watch their behaviour instead. Remarks on food habits and hunting techniques in this paper are based on many observations.

To illustrate the difficulty of assessing the true number of migrating raptors in the area a complete account is given below for one day, which may be considered as average for the second half of March. 
Table 1: Observation days, foothills west of Cochrane, Alberta.

\begin{tabular}{c|ccc|ccc}
\hline \multirow{2}{*}{ year } & \multicolumn{2}{|c|}{ number of days in spring } & \multicolumn{3}{c}{ number of days in fall } \\
\cline { 2 - 7 } & March & April & May & Sept. & Oct. & Nov. \\
\hline 1960 & 4 & 5 & & 2 & 2 & 4 \\
1961 & 4 & 6 & 1 & & & 1 \\
1964 & & 4 & & & 3 & 2 \\
1965 & 4 & 1 & & 1 & 2 & \\
1966 & 6 & 3 & 1 & & 3 & \\
1967 & 8 & 2 & & 2 & 1 & 2 \\
1968 & 6 & 2 & & 6 & 12 & 8 \\
1969 & 32 & 23 & 2 & & \\
\hline
\end{tabular}

Notes on hawks and eagles seen on March 30, 1969:

The first two hours were spent driving west on highway $1 \mathrm{~A}$, starting at Cochrane. During frequent stops the countryside was scanned through binoculars. The remaining five hours were spent on foot. Figures in brackets refer to the number of observations of eagles, not to the actual number of individuals present in the country.

TIME Overcast with pale sun, light $\mathrm{SE}$ winds, $\pm 25^{\circ} \mathrm{F}$.

1000 hrs.: Ad. Bald Eagle perched on tree close to river, (1).

1010: Ad. Bald on fence post (2).

Dark: unidentified eagle on distant hill (3).

1015: Ad. Golden Eagle on fence post. I watched this bird for about 1 hour, during which time it took flight four times and attempted to catch ground squirrels (4). Two other ad. Golden Eagles on distant hills. (5-6)

1030: Imm. Golden circling over fields to the west (7). When an ad. Bald (8) flew by, from west to east, the imm. Golden stooped at it three times. The Bald reacted in the usual manner by executing a swift roll and presenting the outstretched legs at the right moment. Both birds disappeared from view.

1040: Imm. Golden flew by and disappeared eastward (9). I left this observation point.

1130: Overcast, no wind, $30^{\circ}$ F. Golden Eagle on hill side (10). Another on tree (11).

1200: I hiked into the hills. Ad. Gol- den flew by (12).

1210: Ad. Golden on hill top (13).

1300: Installed myself on the top of a hill. Sky cleared, the sun came out and the wind picked up from the west, soon blowing at 25-35 mph.

1305: Golden gliding over opposite slope (14). (Number 13 still perched on same hill top.)

1310: Two ad. Bald Eagles soaring in the west at great altitude (15-16). 1315: Four ad. Bald and one Golden soaring in northwesterly direction and disappearing from view (17-21). 1320: Two dark eagles over hills to the east (22-23).

1330: Three ad. Golden and two ad. Bald soaring in northeast (24-28). Small accipiter (male Cooper's?) soaring north of me.

1340: Ad. Golden sailing low over slopes to the west (29).

13:50: Imm. Bald circling and gliding in northeasterly direction (30).

1400: I left hill top and walked down. Ad. Golden appeared behind me (31). 1405: Ad. Bald and ad. Golden circled over hills far to the southwest (3233).

1415: Ad. Bald circling to the northwest (34).

1420: Imm. Bald and ad. Golden circling southwest of me (35-36). The next hour was spent in a sheltered area, away from the chilling wind. Temperature had risen to about $45^{\circ} \mathrm{F}$. 1430: Ad. Golden soaring nearby (37).

1500: Red-tailed Hawk called and soared overhead.

1530: Hiked back to the look-out hill. 
1610: Arrived on the top and glassed surrourding hill sides and sky. No eagles to be seen.

1630: Walked down. Prairie Falcon soaring and gliding far to the north.

1700: Arrived at car and drove back to Cochrane. Ad. Bald (38) flying over fields to the south and circling low over the road where a crow was feeding on car-killed ground squirrel. Several trucks and cars passed in quick succession. The eagle flew back in the direction it came from and perched on a tree.

\section{Discussion of the above observations}

A total of 38 eagles was observed, but some duplication is to be expected. Eagle no. 7 is probably the same as no. 9. No. 12 may be the same oird as no. 13 , no. 31 as no. 33 and no. 32 as no. 34. Two immature Bald Eagles were seen. It is unlikely that no. 30 , which disappeared from view behind a hill to the northwest of me, was the same as no. 35 seen in a southwesterly direction half an hour later. Yet the bird may have flown in a semi-circle. Often it is possible to identify certain individuals among eagles of one species and the same age group. Not so in this case.

\section{Status of raptors observed in the area}

GOSHAWK (Accipiter gentilis): Regularly seen in spring and fall, but never numerous. Highest number of observations in one day: four on April 23, 1961.

SHARP-SHINNED HAWK (Accipiter striatus): Definite migration in fall. Sighted at a rate of five to 15 birds a day from early September to the middle of October. Birds seen in the last two weeks are adults. At times they soar at great heights, but when the strong westerly winds blow, they wing their way through the valleys. Much less numerous in spring; none to five birds a day.

COOPER'S HAWK (Accipiter cooperii): Occasionaly seen in spring and fall: none to two birds a day.

RED-TA ILED H A W K Buteo jamaicensis): Though common in
August and September I observed no distinct migration. Most breeding birds arrive in April (earliest date March 23, 1967) and leave in September, with an occasional bird moving through until the middle of October.

S W A I N SON'S HAWK (Buteo swainsoni): Summer resident, but less common than previous species. I observed no distinct migration.

ROUGH-LEGGED HAWK (Buteo lagopus): Occasionally seen during spring and fall, less frequently than on the plains farther east.

FERRUGINOUS HAWK (Buteo regalis): Only one observation of a single bird on April 29, 1961.

GOLDEN EAGLE (Aquila chrysaetos): Scarce resident throughout the year. From mid-September to mid-October there is a marked increase in the number of eagles that hunt for Richardson's ground squirrels. It is difficult to count individuals because the same birds may be seen several times. On bright days small numbers of birds soar and glide in a southerly direction, but this movement is not restricted to the foothills. According to my records, Golden Eagles in fall migration are common in the mountains. (On October 4, 1968, 16 birds were seen moving south along a ridge near Rock Lake). They are also seen on the prairies east of Edmonton well into November.

Spring migration presents a different picture. I have no records of birds seen east of Edmonton during numerous observation days in March and April. During that time the foothills may be of special interest due to their relatively short winter. West of Cochrane, exposed slopes are rapidly stripped of snow by strong Chinook winds, and as a rule the ground squirrels are out in the first week of March, at the same time the eagles appear. But again, it is difficult to learn their exact number. From then until the end of April many birds spend a period of time in the area and hunt exclusively for ground squirrels. From day to day the number of eagles may change consid- 


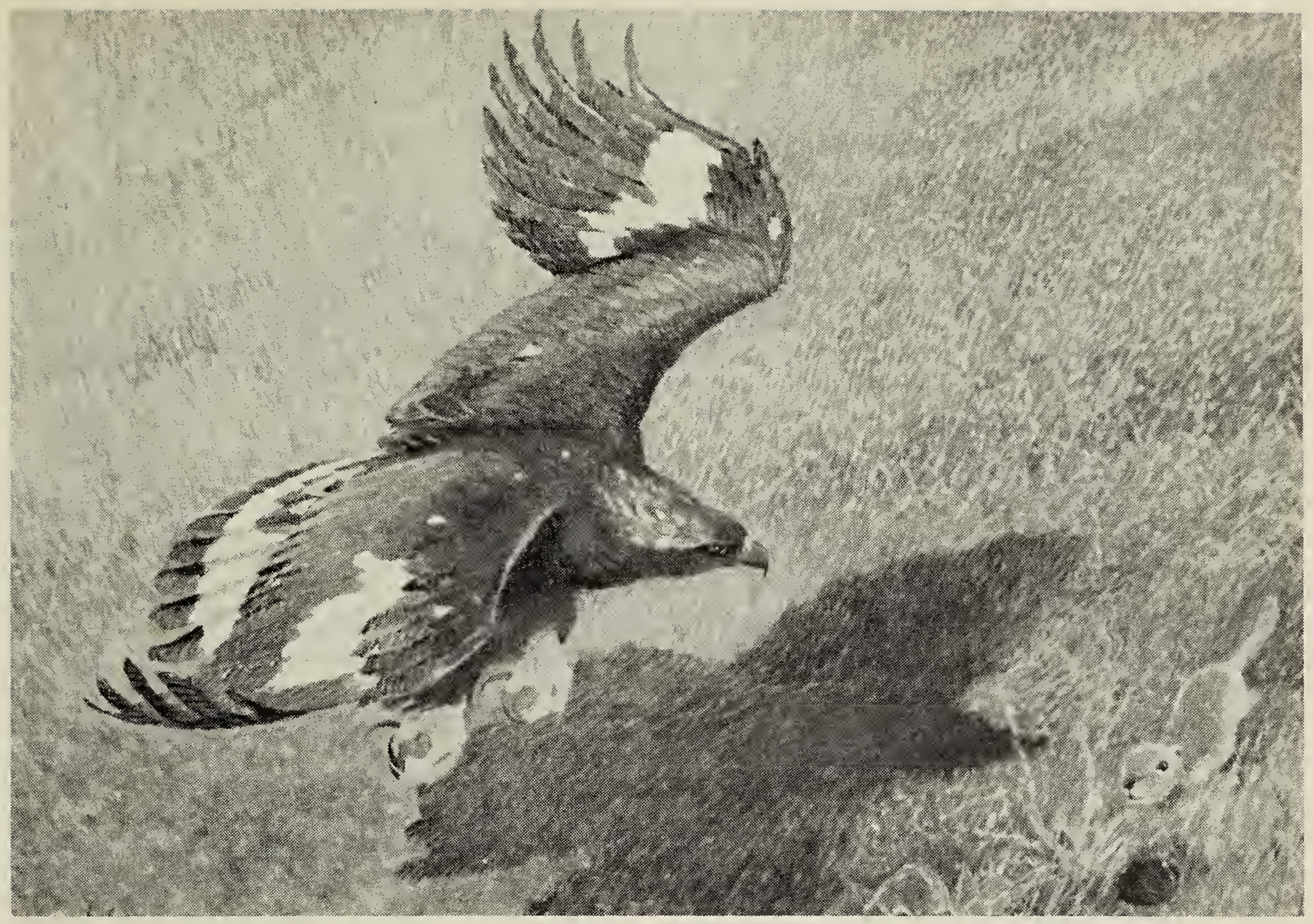

Painting by Dick Dekker Immature Golden Eagle in characteristic low flight hunting ground squirrels

erably. Where one saw several adults the day before, only immatures may hunt along the slopes.

By the middle of March the number of eagles in the area is at times exceptional. On dull days they can be seen perched on hill sides, fence posts and trees. Their activity increases sharply as soon as the strong west wind starts to blow. Looking up at one bird it is common to see others on the move. Ofter the birds travel together in loose flocks at great altitudes. On March 18, 1961, within half an hour, twice a group of seven was observed; on March 19, 1967, within one hour, groups of five, four, and three, plus several singles; on March 24, 1967, groups of seven and five. The birds join each other to soar in a column of rising air. In long glides one follow's the other to the next thermal current. Many birds travel at lower altitudes with steady wing beats, interrupted at times by sailing. These eagles may start to soar over a distant hill and either continue on their way north, or descend and start to hunt, in which case they may be seen and counted again. For these reasons numbers should be calculated with restraint. At the height of the spring migration, however, even conservative estimates can run as high as 50 birds a day.

BALD EAGLE (Haliaetus leucocephalus): Regular fall migrant. From none to five birds seen daily in the first half of October. Scarce thereafter, when many Bald Eagles may still be seen migrating across the plains farther east. More numerous in spring. The first birds are seen in early March. Some appear to stay in the area for a length of time and are seen feeding on carrion and ground squirrels. Road-killed rodents may be often utilized. Migration reaches a peak around the middle of March and levels off to the end of April, with the last birds being immatures. A few outstanding records: a group of eight adults soaring together 
on March 18, 1961; four adults on April 3, 1965, on March 15, 1969 and on March 30, 1969.

A male and a female are often seen together, indicating that some birds travel in pairs. Along the Bow River, downstream from Calgary, I have seen wintering Bald Eagles that were apparently paired with male and female regularly perching in the same trees. On March 28, 1965, an adult male and female were feeding together on a deer carcass near Whitecourt.

It should be noted that spring migration, as well as fall migration, is not restricted to the foothills, but it. may start at an earlier date than farther east on the plains. My earliest record for migrating Bald Eagles for prairie east of Edmonton is March 30, 1967.

HARRIER (Marsh Hawk) (Circus cyaneus): Observed during spring and fall, but less commonly than on the prairies farther east: none to five birds a day.

OSPREY (Pandion haliaetus): Only three observations: April 29 and 30, 1961, September 19, 1967.

PRAIRIE FALCON (Falco mexicanus): Breeds in the area. No migragration observed.

MERLIN (Pigeon Hawk) (Falco columbarius): Scarce summer resident. Few observations in spring and fall.

AMERICAN KESTREL (Sparrow Hawk) (Falco sparverius): Summer resident. Few observations in spring and fall.

\section{Conclusions}

Migrating raptors, west of Cochrane, Alberta, are not noticeably channelled by the Rocky Mountains, with the exception of Sharp-shinned Hawks during the fall, and Golden as well as Bald eagles during the spring. Especially in March the number of eagles is spectacular (up to 50 birds per day) and to my knowledge unique in North America. The total number of fall migrants seen at Hawk Mountain, Pennsylvania, from 1958 to 1967 , averaged 34 for Golden and 39 for Bald eagles for the entire season (Newsletter no. 40, 1968, Hawk Mountain Sanctuary Association).

Eagles on spring migration appear in the study area in the first week of March, which is considered early and may be related to the relatively short winter in the foothills. Areas of semiarid slopes, where snow disappears early due to frequent Chinook winds, extend north at least as far as the Yukon. These areas are also characterized by a relative abundance of wintering hoofed animals. In the study area, Golden Eagles hunt exclusively for Richardson's ground squirrels, whose reappearance from hibernation coincides with the start of the eagle migration. Also, Bald Eagles were seen feeding on ground squirrels, as well as on carrion.

Remarkable is the total absence of Broad-winged Hawk (Buteo platypterus), Peregrine Falcon (Falco peregrinus) and Gyrfalcon (Falco rusticolus) that do migrate on the plains east of Cochrane.

Of special interest is the early date at which the eagles move back to the still solidly frozen north. Until their regular prey becomes available it is to be expected that they depend largely on carrion, such as winterkilled mammals, for food. As wolfkilling campaigns are often carried out as late as the end of March, it is inevitable that eagles will fall victim to poison baits. Several cases in Alberta and the Yukon have come to my attention. In wilderness areas of the Northwest Territories, the Yukon and Saskatichewan it has been the practice to place wolf baits on frozen lakes and rivers for various reasons. One of them is that after break-up the meat sinks and is disposed of "safely." Considering the amount of poisoning that has been carried out in Canada's North, as well as in parts of southern Canada and the western United States, where the eagles winter, I consider it nothing short of a miracle that as many eagles can still be seen as I had the privilege of seeing in the past seven springs. 